\title{
A NEW FRESH-WATER AMPHIPOD FROM VIRGINIA, WITH SOME NOTES ON ITS BIOLOGY.
}

\author{
By George C. Embody, \\ of Cornell University, Ithaca, New York.
}

During the spring of 1908 a number of amphipods were collected by the writer in a spring-fed pond near the town of Ashland, Virginia. Conspicuous among them, for their large size and relatively great abundance, were forms which were then supposed upon hasty examination to be Eucrangonyx gracilis (Smith). More careful study a year later, however, brought to light characters distinctly different from those mentioned in any description of the latter amphipod available to me. ${ }^{a}$ It is believed that these characters are sufficiently constant to warrant a description of this form as a new species.

I am indebted to Dr. I. F. Lewis, of Randolph Macon College, for collecting some forty additional specimens from the same pond where discovered in 1908. From these it has been possible to determine with some degree of accuracy the constancy of the characters noted. To Prof. James G. Needham, under whose direction this study has been made, I am especially grateful for constant advice. I desire, also, to express my sincere thanks to Prof. S. J. Holmes for his kindness in reading the manuscript and for valuable criticisms which he has offered.

EUCRANGONYX SERRATUS, new species.

Description.-Eyes small, with few facets (about twenty-five); in diameter averaging seven-tenths the greatest breadth of the basal segment of the first antenna; circular or slightiy elongated and densely pigmented with black.

First antenna approximating one-half the length of body; peduncle about one-third total length (fig. 1), with numerous setæ projecting from different points along the lateral margin of each segment; first segment equal to or slightly longer than second, third one-half to twothirds of the first; primary flagellum consisting of from twenty to twenty-seven segments, each of which gives off from its distal margin two to five setæ; secondary flagellum composed of two segments, the

a Smith, Am. Journ. Sci., ser. 3, vol. 2, 1871, p. 453. Forbes, Bull. Illinois State Lab., No. 1, 1876, p. 6. Stebbing, Das Tierreich. Amphipoda. 1. Gammaridea, 1906, p. 388. Weckel, Proc. U. S. Nat. Mus., vol. 32, 1907, p. 32. 
distal one, one-third to one-half the proximal and bearing two or three setæ.

Second antenna (fig. 2) about one-half as long as first; flagellum four-fifths as long as the peduncle and composed of from six to eleven segments, each giving off setæ similarly to those of the first antenna; peduncle longer or shorter than that of the first antenna ( and furnished with forty to sixty setæ, often arranged in fascicles of three.

Both pairs of gnathopods similar in the two sexes, the first pair (fig. 3) shorter than the second; propodus longer than broad, the breadth varying from six to seven-tenths of the length, greatest breadth about midway between the extremities; palm convex, very oblique, and armed on either side with from ten to thirteen notched spines of unequal length, one near the posterior angle more than twice the length of the others, and near this four or five smaller spines usually crowded together. Between each pair of notched spines are one or two long hairs. The whole margin of palm is closely set with very fine sharp teeth, to be seen with the high-power objective. Dactyl strongly curved, extending to or slightly beyond the posterior extremity of palm and furnished with two or three hairs. Posterior margin of propodus straight or slightly convex, with eight or ten hairs, some of

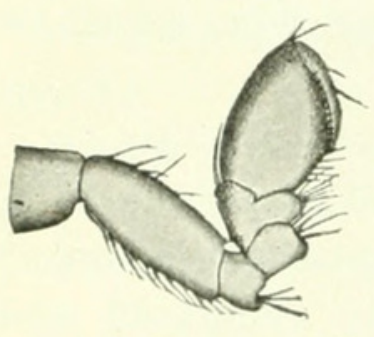

3

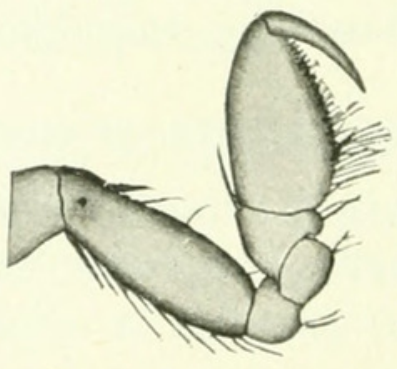

4

Figs. 1-4.-E. Serratus. 1, ANtenNa 1, X 11 Diam.; 2 , ANTENNA $2, \times 11$ DLAM,; 3 , GNATHOPOD 1 , $\times 11$ DIAM.; 4, GNATHOPOD $2, \times 11$ DIAM. which are finely plumose. Carpus as broad as long, posterior margin very convex, produced slightly and armed with two or three setæ and five or six plumose hairs; anterior -margin somewhat convex, with one or two long bristles at its distal angle. Basal joint shorter than that of second gnathopod.

Second gnathopod (fig. 4) longer than first and differing from it as follows: Basal joint one-fourth to one-third longer than that of first gnathopod; propodus one-fifth longer with a larger number of bristles (14 to 18) arranged in fascicles on its posterior margin, its greatest breadth located nearer the proximal end, and hence a more oblique palm.

Fourth peræopod slightly longer than fifth, which is also longer than the first, second, or third; the third, fourth, and fifth with spines on both margins of the basal joints, which latter are also deeply and 
acutely serrated along the posterior edges, forming great teeth in nearly all cases twice as long as the spines between them (fig. 5).

Pleopods with their outer rami slightly shorter than the inner.

Uropods one and two have equal rami; third, with inner ramus rudimentary and very short, about one-third as long as peduncle (fig. 6); outer ramus uniarticulate, with three or four groups of spines on lateral margins and one group of two or three at the distal end. First pair of uropods extending backwards slightly beyond the second which in turn reaches to or slightly beyond the third.

Telson (fig. 7) longer than broad, longer than the peduncle of third uropod and with an emargination extending from slightly more than one-half to nearly twothirds of the distance to base (see table), armed distally with three or four spines on each lobe and on the dorsal surface with three or four spines which seem to be definitely located within the midregion.

The postero-lateral angles of the first three abdominal segments are produced backward, each into a tooth and provided with about five or six spines just above the ventral margin.

Size.-The largest specimen examined was a female with eggs and measured $14.5 \mathrm{~mm}$. in length; the smallest adult, a male measuring 7.6 $\mathrm{mm}$.

Eggs._-The average dimensions of six from different individuals were 0.39 by $0.485 \mathrm{~mm}$.

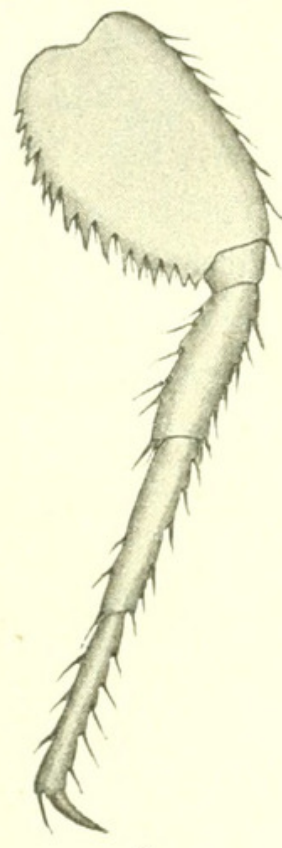

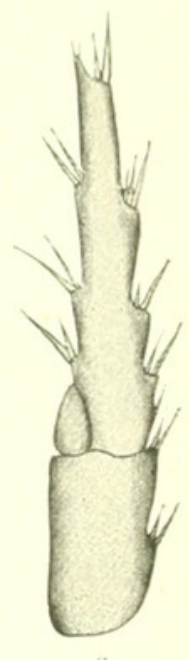

6

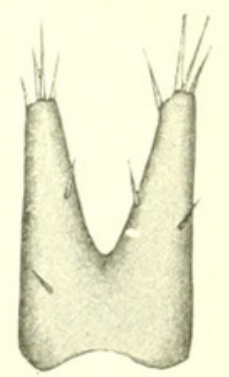

7

Figs. 5-7.-E. Serratus. Pereopod 5, $\times 11$ DIAM.; 6, UROPOD $3, \times 32$ DIAM.; 7, TELSON, $\times 32$ DIAM:

\section{Type-specimen.-Cat. No. 51290, U.S.N.M.}

This species resembles Eucrangonyx gracitis, but differences exist in the telson, basal joints of the third to fifth peræopods, in the gnathopods, and in the size of the eggs.

The telson of $E$. gracilis is as broad as long (see table), not longer than peduncle of third uropod and cleft one-third to one-half the distance to base. ${ }^{a}$ In E. serratus it is longer than broad, longer than

$a$ Early in the work variations in the depth of the emargination of the telson in Eucrangonyx gracilis were noted which had not been accounted for in the descriptions of that species given in the works cited in footnote on a previous page. In order to see just how far these variations had progressed, a number of specimens were collected from a trout brook near Auburn, New York, from Cayuga Lake at Ithaca, New York, and from a sphagnum bog at McLean, New York. The more conspicuous variations are recorded in the table of measurements on page 305 . 
peduncle of third uropod and cleft (typically) nearly two-thirds of the distance to base. The difference in the two species as regards the ratio of the length of peduncle of third uropod to the length of telson is constant in the newly hatched young as well as in the largest adult (see table).

In E. gracitis the third, fourth, and fifth peræopods have their basal joints serrated along the posterior margins but the spines are longer than the adjacent teeth. In E. serratus the depths of the serrations vary, but in all specimens examined the teeth were much Ionger and more acute than those of E. gracitis and about twice the length of the spines between them.

The propodi of gnathopods one and two are proportionately longer in E. serratus, the palms more oblique and more convex, and the carpus of second gnathopods never longer than broad.

Six segmenting eggs of E. gracilis were measured and an average size of 0.256 by $0.334 \mathrm{~mm}$. was obtained, which was less than the same for E. serratus.

Habitat.-The type-specimens were collected March 11, 1908, from the marginal vegetation of " Railroad Pond," about $1 \frac{1}{2}$ miles north of Ashland, Virginia. They were especially abundant in the thickest patches of Sphagnum and Utricularia at depths varying from a few inches to $1 \frac{1}{2}$ feet. Associated with them were large numbers of $E$. gracitis and Hyalella knickerbockeri (Bate).

Differences between young and adult.-It was thought that by comparing the structures in the young of E. serratus with those of the adult and also with those of the young of E. gracitis, some light would be thrown upon the status of the former as a distinct species. Accordingly several young, differing not more than a day in age, were taken from the marsupial pouches of individuals of each form, the various appendages dissected, stained in aqueous eosin and mounted for microscopical examination.

The young of E. serratus were found to differ from their parents in the following particulars:

(1) First antenna (fig. 9): Primary flagellum composed of but four segments all proportionately longer than those of the adult.

(2) Second antenna (fig. 8): Flagellum composed of but three segments.

(3) First gnathopod (fig. 10): Great angularity of the region at the junction of the palm and the posterior margin of propodus. The latter is proportionately smaller and its posterior margin destitute of spines and hairs. The palm is straight, less oblique and thickly covered on both sides with minute sharp teeth. These teeth are much more evident in the young than in the adult. 
(4) Second gnathopods (fig. 11): Palm straight or slightly concave, possessing a small angular prominence at the posterior extremity, the inner margin of this prominence together with the remaining margin of the palm closely set with minute teeth as in gnathopod one; posterior margin of propodus destitute of spines and hairs.

(5) Third, fourth, and fifth peræopods destitute of spines and serrations.

(6) Uropod one, shorter, not reaching backward to the end of second uropod.

(7) Uropod three (fig. 12 ), with three spines, two short ones at the apex and one long one on the outer margin of the outer ramus.

(8) Telson (fig. 16) with lateral margins very convex, not quite so long as in the adult but distinctly longer than peduncle of third uropod; emargination not quite so deep as in adult. The apex of each lobe is armed with a single spine while the mid-dorsal region of the telson is minus spines.

(9) Eyes brownish in life.

Differences between young of Eucrangonyx gracilis and E. serratus.The following differences between the young of these two species were found to be constant in all specimens examined:
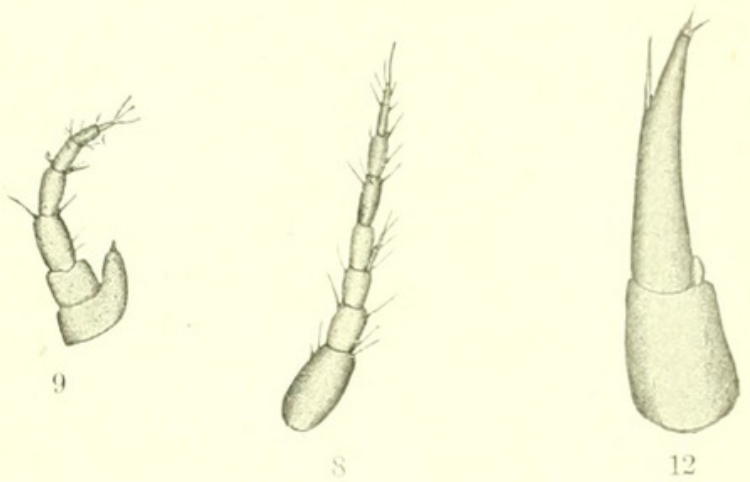

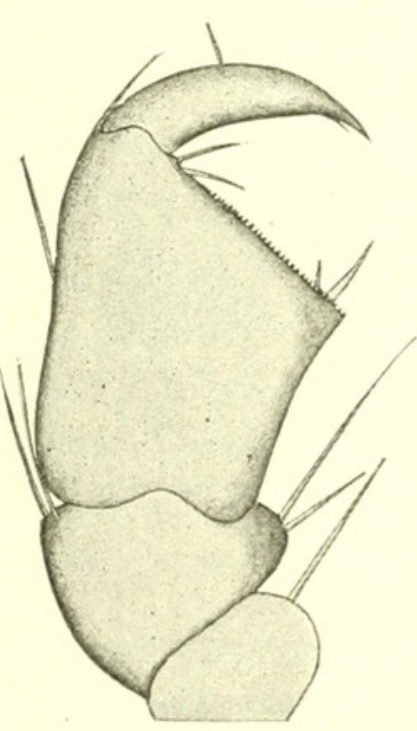

10

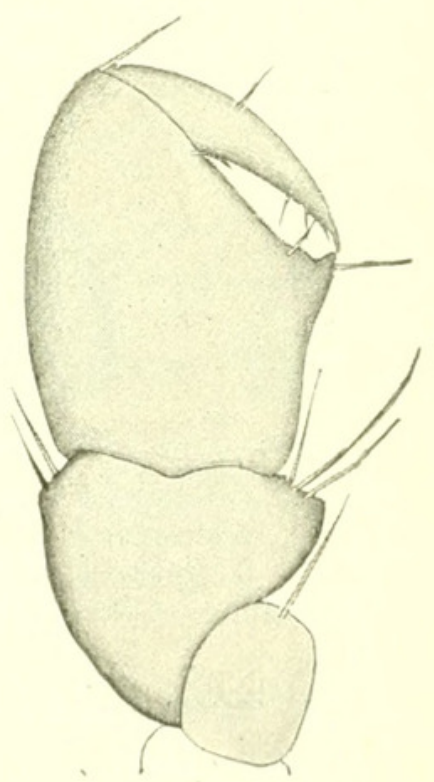

11
Figs. 8-12.-E. Serratus (Young). Antenna 1, X 32 diam.; 9 , ANTENNA $2, \times 32$ DLAM.; 10 , GNATHOPOD 1 , $\times 159$ DIAM.; 11 GNATHOPOD $2, \times 159$ DIAM.; 12 , UROPOD $3, \times 159$ DIAM.

(1) Young E. serratus are 25 per cent longer than E. gracitis.

(2) The propodus of first gnathopod in E. serratus is broader distally, the palm forming a prominent angle of $45^{\circ}$ or less with the posterior margin, which latter is decidedly concave. In E. gracilis (fig. 13), the junction of these two margins is well rounded.

(3) The palm in gnathopod two is decidedly more oblique in E. serratus, and as noted previously possesses an angular prominence at the 
posterior extremity which is entirely lacking in E. gracilis (fig. 14); carpus as broad as long in the former species, while in the latter it is longer than broad.

(4) The differences existing in the adult telson in the two species are present to some degree in the young. In serratus the telson is but slightly, if at all, longer than broad, much longer than peduncle of third uropod, emargination $\mathrm{V}$-shaped and extending beyond onehalf the distance to base (see table); that of E. gracitis broader than

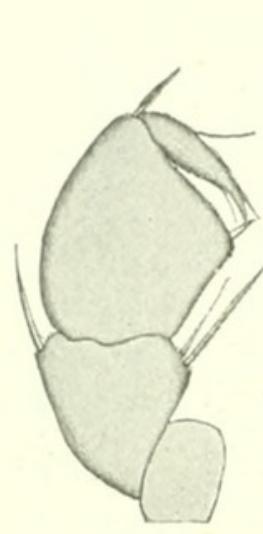

13

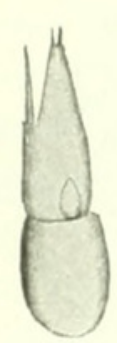

15

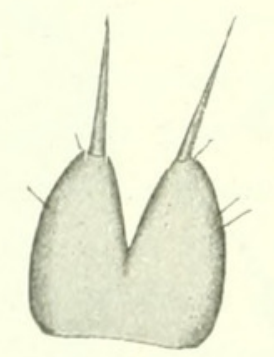

16

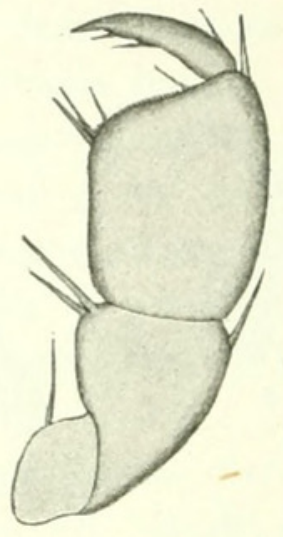

14

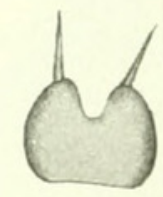

17
Figs. 13-17.-E. GRACHLIS (YOUNG). GNATHOPOD $1, \times 159$ DIAM :; 14, GNATHOPOD $2, \times 159$ DIAM.; 15 , UROPOD $3, \times 159$ DLAM.; 16, E. SERRATUS (YOUNG). TElson, X 159 DiAM.; 17, E. gracilis (young). TElson, X 159 DIAM.

long, shorter than peduncle of third uropod, emargination U-shaped and extending about one-third the distance to base (figs. 15 and 17). In each species the telson is armed distally on each lobe with a single long, stout spine.

Notes on the reproductive capacity. - A large number of the specimens examined were females with eggs in their pouches. In many cases the eggs were counted and certain measurements taken in order to show some correlation between the number of eggs and the size or age of the individual, and to give an idea of the reproductive capacity of the species.

Several specimens of E. gracilis were treated in a similar manner for comparison. The results of the observations concerning both species are herewith given in tabular form.

An examination of this table shows clearly that in general the larger individuals, and hence the older, possess the larger number of segments in the primary flagellum of first antenna, and also that the larger complements of eggs are deposited by the larger fem ales.

In the six largest individuals measured, those from 12.8 to 14.5 $\mathrm{mm}$. long, the average number of eggs was eighty-two. In three individuals of medium size, from 9.7 to $11.5 \mathrm{~mm}$. long, the average was forty-four. 
Table of measurements.

\begin{tabular}{|c|c|c|c|c|c|c|c|c|c|c|c|c|}
\hline \multirow[b]{2}{*}{ 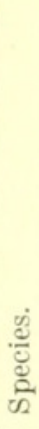 } & \multirow{2}{*}{ 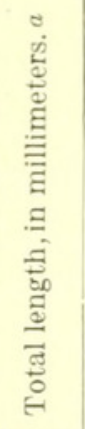 } & \multicolumn{2}{|c|}{$\begin{array}{l}\text { Number } \\
\text { segments in } \\
\text { primary } \\
\text { flagellum } \\
\text { of first } \\
\text { antenna. }\end{array}$} & \multicolumn{2}{|c|}{$\begin{array}{l}\text { Number } \\
\text { segments in } \\
\text { flagellum } \\
\text { of second } \\
\text { antenna. }\end{array}$} & \multicolumn{2}{|c|}{ Telson. } & \multirow{2}{*}{ 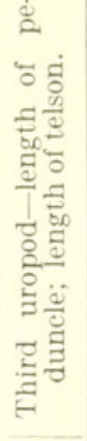 } & \multirow{2}{*}{ Sex. } & \multirow[b]{2}{*}{ 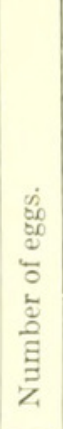 } & \multirow{2}{*}{ Date. } & \multirow{2}{*}{ Locality. } \\
\hline & & $\frac{\vec{d}}{\frac{\Delta 0}{01}}$ & 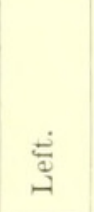 & $\frac{\vec{J}}{\frac{100}{0}}$ & $\underset{\square}{\stackrel{\leftrightarrows}{\oplus}}$ & 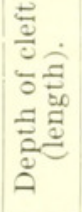 & 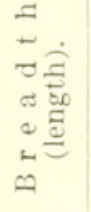 & & & & & \\
\hline 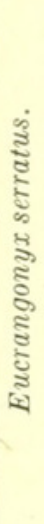 & $\begin{array}{l}2.45 \\
2.26 \\
7.6 \\
8.3 \\
9.7 \\
10.2 \\
10.7 \\
10.7 \\
11.5 \\
12.00 \\
12.8 \\
12.8 \\
12.8 \\
12.15 \\
14.00 \\
14.00 \\
14.00 \\
14.5\end{array}$ & $\begin{array}{r}4 \\
4 \\
19 \\
17 \\
21 \\
21 \\
23 \\
22 \\
23 \\
24 \\
26 \\
\ldots \ldots \\
\ldots \\
27 \\
\ldots \ldots \\
\ldots \ldots \\
27 \\
27\end{array}$ & $\begin{array}{r}4 \\
4 \\
19 \\
18 \\
21 \\
21 \\
22 \\
22 \\
23 \\
24 \\
26 \\
\ldots \ldots \\
\ldots \ldots \\
\ldots \ldots \\
\ldots \ldots \\
\ldots \ldots \\
27\end{array}$ & $\begin{array}{r}3 \\
3 \\
8 \\
8 \\
\ldots . \\
9 \\
10 \\
10 \\
10 \\
10 \\
10 \\
\ldots \ldots \\
\ldots \\
10 \\
9 \\
\ldots \ldots \\
11 \\
\ldots\end{array}$ & $\begin{array}{r}3 \\
3 \\
7 \\
8 \\
\ldots \\
9 \\
10 \\
10 \\
10 \\
9 \\
8 \\
\ldots \ldots \\
11 \\
10 \\
\ldots \ldots \\
\ldots \ldots \\
11\end{array}$ & $\begin{array}{c}0.533 \\
.52 \\
.52 \\
.58 \\
\ldots . .5 \\
.507 \\
.607 \\
.626 \\
.535 \\
.57 \\
.61 \\
\ldots . \\
\ldots \ldots\end{array}$ & $\begin{array}{l}1.00 \\
.954 \\
.77 \\
.80 \\
\cdots .676 \\
.78 \\
.723 \\
.666 \\
.685 \\
.634 \\
\cdots \\
\cdots\end{array}$ & $\begin{array}{l}0.77 \\
.795 \\
.82 \\
77 \\
\ldots . \\
.76 \\
.76 \\
.843 \\
.82 \\
.77 \\
66 \\
\ldots \ldots \\
\ldots \ldots \\
\ldots \ldots \\
\ldots .8 \\
.8 \\
.8\end{array}$ & 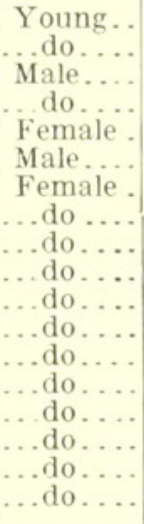 & \begin{tabular}{l}
$\ldots$ \\
$\cdots$ \\
$\cdots$ \\
42 \\
$\cdots$ \\
\hdashline 5 \\
45 \\
46 \\
77 \\
70 \\
66 \\
92 \\
95 \\
98 \\
88
\end{tabular} & 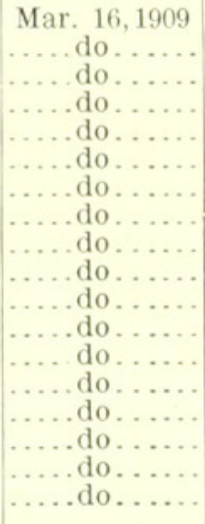 & $\begin{array}{c}\text { Ashland, Virginia. } \\
\text { Do. } \\
\text { Do. } \\
\text { Do. } \\
\text { Do. } \\
\text { Do. } \\
\text { Do. } \\
\text { Do. } \\
\text { Do. } \\
\text { Do. } \\
\text { Do. } \\
\text { Do. } \\
\text { Do. } \\
\text { Do. } \\
\text { Do. } \\
\text { Do. } \\
\text { Do. } \\
\text { Do. }\end{array}$ \\
\hline 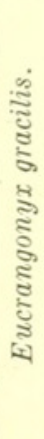 & $\begin{array}{l}1.7 \\
5.6 \\
6 \\
6 \\
7.6 \\
8.5 \\
9 \\
9 \\
9 \\
9 \\
9.5 \\
10.45 \\
11.5\end{array}$ & $\begin{array}{r}4 \\
\\
18 \\
19 \\
18 \\
20 \\
20 \\
21 \\
22 \\
22 \\
23 \\
23 \\
24 \\
27\end{array}$ & $\begin{array}{r}4 \\
18 \\
19 \\
15 \\
21 \\
\ldots \ldots \\
\cdots \ldots . \\
\cdots \ldots . \\
\cdots \\
23 \\
24 \\
28\end{array}$ & $\begin{array}{l}8 \\
8 \\
9 \\
9 \\
8 \\
8\end{array}$ & $\begin{array}{r}8 \\
8 \\
8 \\
\cdots \cdots \\
\cdots \cdots \\
\cdots \cdots\end{array}$ & $\begin{array}{l}.322 \\
.235 \\
\ldots \\
.5 \\
.36 \\
.22 \\
.40 \\
.316 \\
.50 \\
.26 \\
.50 \\
.31 \\
.35\end{array}$ & $\begin{array}{l}1.29 \\
1.176 \\
1.00 \\
1.08 \\
1.166 \\
1.05 \\
1.10 \\
1.16 \\
1.24 \\
1.00 \\
1.1 \\
1.07\end{array}$ & $\begin{array}{l}1.19 \\
1.12 \\
1.22 \\
1.12 \\
1.12 \\
1.21 \\
1.08 \\
1.11 \\
1.24 \\
1.05 \\
1.035\end{array}$ & $\begin{array}{l}\text { Young.. } \\
\text { Female. } \\
\text {.do.... } \\
\text { Male.... } \\
\text { Female. } \\
\text {.. do.... } \\
\text {... do..... } \\
\ldots \text {.. do.... } \\
\ldots \text {...do..... } \\
\text {.do.... } \\
\text { Male.... } \\
\text { Female. } \\
\text { Male.... }\end{array}$ & $\begin{array}{c}25 \\
\ldots \\
\cdots \\
34 \\
69 \\
93 \\
52 \\
59 \\
57 \\
\ldots \\
68 \\
\ldots\end{array}$ & 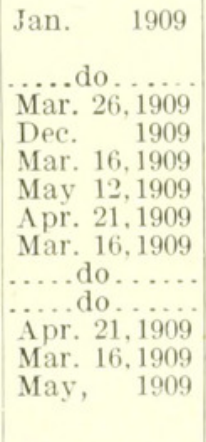 & $\begin{array}{l}\text { Auburn, New } \\
\text { York. } \\
\text { Do. } \\
\text { Ithaca, New York. } \\
\text { Do. } \\
\text { Ashland, Virginia. } \\
\text { Ithaca, New York. } \\
\text { Do. } \\
\text { Ashland, Virginia. } \\
\text { Do. } \\
\text { Do. } \\
\text { Ithaca, New York. } \\
\text { Ashland, Virginia. } \\
\text { McLean Bog, New } \\
\text { York. }\end{array}$ \\
\hline
\end{tabular}

$a$ Exclusive of the antennæ.

The pond where this species lived in such great abundance was roughly 3 acres in area, fed by springs within the pond itself and by a small brook at one end. Fish were abundant and from an examination of stomachs of large-mouthed bass (Micropterus salmoides), common sunfish (Lepomis gibbosus), and calico bass (Pomoxis sparoides) it was found that they helped themselves liberally to amphipods. Especially was this the case with the smaller sunfishes and calico bass, 1 to 3 inches long, a few of which were able to penetrate the thick masses of sphagnum where amphipods were exceedingly numerous. This great fringe of vegetation about the pond, however, furnished a shelter which prevented at all seasons any very great destruction of amphipods by predatory animals, and this, together with the rather large reproductive capacity of the species in question, was sufficient reason for their great abundance.

Proc.N.M.vol.38-10-20 


\section{$2 \mathrm{BHL}$ Biodiversity Heritage Library}

Embody, George Charles. 1910. "A new fresh-water amphipod from Virginia, with some notes on its biology." Proceedings of the United States National Museum 38(1746), 299-305. https://doi.org/10.5479/si.00963801.38-1746.299.

View This Item Online: https://www.biodiversitylibrary.org/item/32576

DOI: https://doi.org/10.5479/si.00963801.38-1746.299

Permalink: https://www.biodiversitylibrary.org/partpdf/36086

\section{Holding Institution}

Smithsonian Libraries

\section{Sponsored by}

Smithsonian

\section{Copyright \& Reuse}

Copyright Status: NOT_IN_COPYRIGHT

This document was created from content at the Biodiversity Heritage Library, the world's largest open access digital library for biodiversity literature and archives. Visit BHL at https://www.biodiversitylibrary.org. 